\title{
ODNOWIENIE FUNKCJI ADWOKATA PRZY SĄDACH KOŚCIELNYCH
}

\section{Wstęp}

Tak w prawie kanonicznym, jak i w świeckim kategoriami metajurydycznymi są: prawda i dobro. Im służyć winno każde prawo i wszyscy uczestnicy procedur prawnych, szczególnie procesów sądowych. Jest to wytyczna także dla stron postępowania sądowego oraz ich adwokatów.

W ostatnich latach funkcja adwokata w procesie kanonicznym przeżywa swój renesans. Po wiekach złych doświadczeń z adwokatami Kościół znowu okazał im większe zaufanie. W związku z coraz większą świadomością znaczenia praw człowieka, także w Kościele, wierni coraz częściej chcą z tych praw korzystać. A Kościół nie tylko im na to pozwala, lecz także zachęca do tego.

W sądach kościelnych najczęściej prowadzonymi procesami są procesy o nieważność małżeństwa. W tych też sprawach adwokaci najczęściej mogą występować. Zawsze należy pamiętać, że zadaniem tak sędziego, jak i stron procesowych oraz ich adwokatów podczas procesu jest odtwarzanie, przypominanie faktów, a nie ich tworzenie.

\section{Zarys historyczny udziału adwokatów kościelnych}

W Piśmie św. są świadectwa, że występowali obrońcy, ale jeszcze nie adwokaci. Jednak już w III wieku pojawiają się wyraźnie adwokaci. Ze świadectw XIII wieku dowiadujemy się, że adwokaci nie zawsze byli uczciwi. Nasilenie się tego zjawiska w XVIII wieku spowodowało, że papież zakazał udziału adwokatów w procesach. W XIX i XX wieku toczono spory o udział adwokatów. Szczególnie w II połowie

I. Grabowski, Adwokatura w ustawodawstwie kościelnym, „Ateneum Kapłańskie” 1935, t. 35, s. 253 
XX wieku i na początku wieku XXI toczyła się i toczy ożywiona dyskusja na temat udziału adwokatów w kościelnych procesach małżeńskich.

Kodeks Prawa Kanonicznego z 1917 r. udział adwokatów w procesach unormował w kan. 1655-1666. W 1936 r. zostały one uzupełnione art. 43-54 Instrukcji „Provida Mater"2. Jednak w 1946 r. kardynał Hlond znowu zakazał udziału adwokatów w Sądzie Metropolitalnym w Warszawie.

\section{Potrzeba udziału adwokata w sprawach o nieważność małżeństwa}

Pius XII w przemówieniu do audytorów Roty Rzymskiej z 1944 r. podkreśla znaczenie niektórych czynności adwokata. Wcale nie określa on czynności adwokata jako zbędne lub jako nadużycie, lecz stwierdza pewne fakty. Opisuje zakres pracy adwokata jako doradcy i obrońcy, który gdyby nie czynił tego, co do niego należy, sprzeniewierzałby się swoim obowiązkom. Papież zauważył, że świat jest zbyt podejrzliwy w stosunku do osób występujących w procesie ${ }^{3}$. Pius XII podkreślał, że adwokat, podobnie jak sędzia i obrońca węzła małżeńskiego, ma dążyć do prawdy o konkretnym małżeństwie ${ }^{4}$. W obronie adwokatów, czasem niesłusznie posądzanych o nieuczciwość, występowali też profesorowie KUL i innych uczelni ${ }^{5}$.

Kardynał Zenon Grocholewski, wieloletni sekretarz i prefekt Najwyższego Trybunału Sygnatury Apostolskiej i bliski doradca Ojca św. Jana Pawła II, wskazuje na wielkie ,znaczenie roli adwokata dla właściwego przeprowadzenia procesu. Strona bowiem często nie zna problemów prawnych związanych ze sprawą ani też zasad dowodzenia. Adwokat nie tylko będzie wiedział, jakie dowody przedstawić, ale też np. gdy chodzi o świadków, zaproponuje odpowiednie kwestie mające być przedmiotem przesłuchania" ". Zapewne odnosi się to także do przesłuchania stron.

Adwokat wie, co z historii małżeństwa, opowiedzianej przez stronę, ma ważne znaczenie dla procesu. Ewentualne braki wcześniej złożonej skargi może ona naprawić poprzez dołączenie do przesłuchań pytań dopasowanych do wzmiankowanych w aktach i relacjonowanych w rozmowach z nim faktów, które mają istotne znacze-

S. Congregatio de disciplina sacramentorum. Instructio servanda a tribunalibus dioecesanis in pertractandis causis de nullitate matrimoniorum Provida Mater Ecclesia (15 VIII 1936). AAS 1936, vol. 28, s. 313-361. J. Grzywacz, Adwokaci, pełnomocnicy procesowi, instytucja stałych obrońców (kan. 1490). Referat wygłoszony w czasie Międzynarodowego Sympozjum dla pracowników Trybunałów Kościelnych w Europie ŚrodkowoWschodniej w Lublinie 19-21 września 1991 roku, mps. s. 12. R. Sobański, Udział adwokata w procesie o nieważność małżeństwa, „Jus Matrimoniale” 1997, t. 2, z. 8, s. 131132.

5 J. Grzywacz, op. cit.

6 Z. Grocholewski, Struktura etapu dowodowego procesu, (w:) Plenitudo legis dilectio. Księga pamiątkowa dedykowana prof. dr. hab. Bronisławowi W. Zubertowi OFM z okazji 65. rocznicy urodzin, pod red. A. Dębińskiego i E. Szczot, Lublin 2000, s. 362. 
nie dla dotarcia do prawdziwego obrazu zawieranego małżeństwa, a w konsekwencji do sprawiedliwego rozstrzygnięcia. Sędziowie nie powinni być niechętni dołączaniu przez adwokata pytań, gdyż wspólnym interesem ich, obrońców węzła oraz adwokatów, jako osób znających prawo i uczciwych, a więc działających zgodnie z interesem Kościoła, jest dotarcie do prawdy i wydanie sprawiedliwego wyroku. Dlatego należy popierać udział adwokatów w sprawach o nieważność małżeństwa, stwarzać im odpowiednie warunki pracy, nie tylko na płaszczyźnie finansowej, lecz także mentalnej pracowników sądowych ${ }^{7}$.

Jak wyżej wspomniałem, w ostatnich dziesięcioleciach Kościół okazał adwokatom kościelnym większe zaufanie. Wyraziło się to w normach kodeksowych ${ }^{8}$, a jeszcze bardziej w instrukcji procesowej Dignitas connubii ${ }^{9}$. Odpowiedzią na takie stanowisko Kościoła, a także wynikiem szczegółowych upomnień w tym względzie ze strony Stolicy Apostolskiej, jest powrót adwokatów do występowania w sprawach prowadzonych przez sądy kościelne, który ma miejsce także w Polsce, choć nie bez oporów, a więc wolniej ${ }^{10}$. Wskutek upomnień Sygnatury Apostolskiej w ostatnich latach we wszystkich diecezjach w Polsce zatwierdzono adwokatów kościelnych. Niektórzy z nich pełnią faktycznie swoje funkcje, a niektórzy występują tylko na liście, a tylko w niewielkim zakresie podejmują się obowiązków adwokata ${ }^{11}$.

Zdaniem jednego z polskich kanonistów, specjalistów prawa procesowego, współpraca sędziego $\mathrm{z}$ adwokatem, który więcej czasu poświęca stronie może być ułatwieniem dla pracy sędziego. Wiadomości, jakie posiada strona, o pewnych zdarzeniach z życia, mogą zaważyć na wyroku. Gdy adwokat sporządza wykaz okoliczności, na które strona lub świadek ma być pytany, jakie od strony zna, przeprowadza się dowodzenie o wiele bardziej trafne, oszczędzając czas i zbędny wysiłek. W pro-

Tak też wypowiada się jeden ze znanych oficjałów i znawca prawa kanonicznego: R. Sobański, op. cit., s. 139143. Twierdzi on, że udział adwokatów służy stronom i sądowi, zaś adwokaci prywatni (nie urzędowi, działający na podstawie kan.1490 KPK) winni być przez strony wynagradzani na zasadach rynkowych. Por. G. Stork, Der Kirchenanwalt im kanonischen Recht, (Forschungen zur Kirchenrechtswissenschaft, Bd. 31), Würzburg 1991 R. Sztychmiler, Potrzeba udziału adwokata w procesie o nieważność małżeństwa, „Biuletyn Stowarzyszenia Kanonistów Polskich" 1994, vol. 4, nr 1 (6), s. 28-38. Codex luris Canonici. Auctoritate loannis Pauli pp. II promulgatus. Kodeks Prawa Kanonicznego. Przekład polski zatwierdzony przez Konferencję Episkopatu. Pallottinum 1984, zob. kan. 1559, 1678

9 Pontificium Consilium de Legum Textibus, Instructio servanda a tribunalibus dioecesanis et interdioecesanis in pertractandis causis nullitatis matrimonii „Dignitas Connubii“, Libreria Editrice Vaticana 2005, zwł. art. 101-105.

W 2007 roku powołany został Korpus Adwokatów Kościelnych w Polsce, do którego akces zgłosiła część adwokatów zatwierdzonych przez swoich biskupów. Aktualnie przewodniczacym Korpusu jest ks. prof. dr hab. Ryszard Sztychmiler (zob. www.adwokatsztychmiler.olsztyn.pl). Korpus współpracuje z Radą Prawną Konferencji Episkopatu Polski. Niektórzy zatwierdzeni adwokaci nie garna się do Korpusu, wyrażając obawy zbytniego uzależnienia od ogólnopolskich struktur kościelnych. Osoby podające się za adwokatów kościelnych, a niemające zatwierdzenia żadnego biskupa, nie są legalnymi adwokatami i nie mogą należeć do Korpusu Adwokatów Kościelnych w Polsce.

J. Krzywkowska, Adwokat w sprawach o nieważność małżeństwa. Rozwiązania ustawodawcze i ich zastosowanie w sadach kościelnych w Polsce (1983-2007), mps, Arch UKSW, s. 11-164. 
cesie każdy uczestnik ma swoje przepisane prawem zadania. Ważne znaczenie mają też zadania adwokata ${ }^{12}$.

O wielkim znaczeniu udziału adwokata w procesach kościelnych pisze też jeden z oficjałów polskich: „Nie do przecenienia jest rola adwokata w postępowaniu dowodowym. Zgodnie z kan. 1678 § 1 KPK adwokat ma prawo być obecny podczas przesłuchania stron oraz świadków. [...] Co więcej, ma prawo za pośrednictwem sędziego formułować konkretne pytania zarówno stronom, jak i świadkom, a więc w pewnym sensie ukierunkowywać przesłuchanie na zagadnienia i fakty mogace stanowić dowód w procesie, który się toczy. Zakres pytań jest bardzo szeroki i dotyczy zarówno kwestii przedstawionych w skardze powodowej, jak i wynikających z innych środków dowodowych. Adwokat nie tylko przedstawia środki dowodowe, ale także ocenia zarzuty i argumenty przeciwnika w trakcie procesu oraz redaguje pisma procesowe kierowane do trybunału. Ponadto adwokat informuje stronę o przysługujących jej prawach oraz o ewentualnej potrzebie zgłaszania nowych świadków czy innych dowodów ${ }^{13}$.

\section{Prawo powołania adwokata}

Osoby zainteresowane prowadzeniem procesu o nieważność małżeństwa moga korzystać z pomocy osób, które dobrze znają prawo kanoniczne. Na ogół porada taka związana jest z osobistym zgłoszeniem się u adwokata-kanonisty. Tylko u adwokata kościelnego, który ukończył prawo kanoniczne i jest zatwierdzony przez biskupa, porada jest miarodajna i tylko takiego sędzia może dopuścić do udziału w procesie.

W kan. $1481 \S 1$ KPK prawodawca postanowił: „Strona może swobodnie ustanowić sobie adwokata i pełnomocnika”. Zaś w $\S 3$ dodał: „W sprawie spornej, jeżeli chodzi o małoletnich albo o proces dotyczący dobra publicznego, z wyjątkiem spraw małżeńskich, stronie, która nie posiada obrońcy, sędzia ma go mianować z urzędu". Zatem w sprawach dobra publicznego zasadniczo (bo z wyjątkiem spraw małżeńskich) oraz sprawach małoletnich strona ma prawo do adwokata z urzędu. W innych sprawach ma tylko możliwość skorzystania z wyznaczenia pełnomocnika

„Wiadomo jak ważne sa positiones dla świadków i jak wielka, wagę przywiąuje do nich prawo. Nikt jednak tego nie robi a nawet nie próbuje robić i często kwadransami świadek jest pytany o wiele rzeczą o których zupełnie nie wie, a okazuje się, że jego wiadomości o jednym czy drugim fragmencie życia, ale wiadomości które moga zaważyć na wyroku. Sędzia działa na ślepo, bez pytań stron na jakie okoliczności świadek ma składać zeznania, w rezultacie traci czas na pytania o rzeczach zupełnie bezużytecznych dla procesu. Gdyby adwokat sporzadził wykaz okoliczności, na które świadek ma być pytany, jakie rzeczywiście zna, można by przeprowadzić dowód ze świadków o wiele bardziej ekonomicznie, oszczędzając czas, pracę i nerwy. W procesie każdy uczestnik ma swój określony udział. Jak widzimy nie mały udział ma także adwokat"; zob. J. Grzywacz, op. cit., s. 13.

G. Leszczyński, Urząd adwokata stałego w świetle Instrukcji Dignitas connubii, „Jus Matrimoniale 2006, t. 11, z. 17, s. 150. Zob. tenże, Oświadczenia stron jako środek dowodowy w procesie o stwierdzenie nieważności małżeństwa, „Prawo Kanoniczne" 2000, t. 43, nr 1-2, s. 108-109. 
i/lub adwokata. Strona może ich ustanowić lub nie; jest to dziedzina jej swobodnego wyboru. W art. $101 \S 1-2$ Instrukcji procesowej Dignitas connubii (skrót: DC) powtórzono prawo strony do adwokata, a nawet je rozszerzono, wprowadzając możliwość wyznaczenia przez przewodniczącego trybunału adwokata dla strony.

W sprawach o nieważność małżeństwa adwokat nie jest konieczny, ponieważ zaskarżone jest małżeństwo, jego ważność, a nie strona pozwana. Ono jest bronione przez obrońcę węzła małżeńskiego, który zobowiązany jest także do szukania prawdy (kan. $1432 \mathrm{KPK}$ ). W sądach diecezjalnych strona nie musi powoływać adwokata, lecz może go powołać, jeśli uzna to za konieczne lub wskazane.

Tylko w Rocie Rzymskiej w każdej sprawie występują adwokaci. Do niedawna, jeśli strona mieszkająca w Polsce przyjęła adwokata wyznaczonego z urzędu, Rota ponosiła koszty z tym związane; jeśli jednak strona dokonała wyboru adwokata, sama musiała go opłacić. Od kilku lat strony z Polski są traktowane podobnie jak z innych krajów i muszą ponosić koszta związane z procesem w Rocie.

W omawianym kan. $1481 \S 1$ zawarta jest norma pomocnicza dla sędziego, który także w sprawie spornej, także w sprawie o nieważność małżeństwa, może przydzielić stronie adwokata, jeśli uzna jego posługę za konieczną. Może to zachodzić np. w sytuacji, gdy strona jest głuchoniema lub nie zna języka krajowego. Podobna norma zawarta została w art. $101 \S 2$ DC.

Także w kanonach normujących postępowanie w sprawach o stwierdzenie nieważności małżeństwa zawarty jest przepis (kan. 1678 § 1) mówiący o udziale obrońcy. A obrońca (patronus) jest także adwokat ${ }^{14}$. Jego udział jest szczególnie ważny m.in. dlatego, iż tylko obrońca (a nigdy sama strona) może być obecny przy przesłuchaniach stron, świadków i biegłych.

Zgodnie z kan. 1482 § 1 i 3: „Każdy może sobie ustanowić tylko jednego pełnomocnika [...] 3. Można natomiast ustanowić równocześnie kilku adwokatów". W kanonie tym prawodawca reguluje kwestię ilości pełnomocników i adwokatów w jednej sprawie. Wszystkie trzy paragrafy omawianego kanonu przejęte zostały z kan. $1656 \mathrm{KPK}$ z 1917 r. (§ 1-3). Nie przejęto tylko paragrafu czwartego. A to dlatego, iż zawierał on zbędną obecnie (ze względów redakcyjnych) normę o możliwości sprawowania przez jedną osobę i w tej samej sprawie zarówno funkcji pełnomocnika, jak i adwokata. Normę tę słusznie uznano w Komisji Kodyfikacyjnej za zbędną, gdyż nigdzie nie ma zakazu łączenia wspomnianych funkcji ${ }^{15}$.

Z kan. 1620 nr 7 KPK wynika, iż nikomu nie wolno odmówić wzięcia adwokata, gdyż odmowa którejkolwiek stronie prawa do obrony powoduje nieusuwal-

14 H. Siemer, Anwaltspflicht im kirchlichen Ehenichtigkeitsprozeß? Essen 1996 (Münsterischer Kommentar zum 
ną nieważność wyroku. Przypomniał o tym także Jan Paweł II w przemówieniu do Roty Rzymskiej z 26 I 1989 r. ${ }^{16}$ Strona ma prawo do obrony na każdym etapie pro$\operatorname{cesu}^{17}$.

W postępowaniu o dyspensę od małżeństwa niedopełnionego sędzia zasadniczo nie może dopuścić adwokata; lecz w wyjątkowo trudnej sprawie może dopuścić biegłego w prawie (kan. $1701 \S 2$ KPK). Może on pomagać wnioskodawcy w prowadzeniu postępowania, lecz nie ma takich uprawnień jak adwokat w sprawie o nieważność małżeństwa.

\section{Kwalifikacje adwokata}

Pewne wymagania stawiane adwokatowi są tożsame z wymaganiami stawianymi pełnomocnikowi, a inne stawiane są tylko adwokatom. W kan. 1483 KPK prawodawca kościelny określa wymagania stawiane pełnomocnikom i adwokatom: „Pełnomocnik i adwokat winni być pełnoletni i nienaruszonej sławy. Adwokat ma być ponadto katolikiem, chyba że biskup diecezjalny zezwoli inaczej, doktorem prawa kanonicznego lub skądinąd prawdziwie biegłym i zatwierdzonym przez tegoż biskupa". Adwokatom stawia się więc wyraźnie większe wymagania.

Może być sytuacja, że ta sama osoba pełni urząd pełnomocnika i adwokata, a mogą to być też osoby różne. Słuszne wydaje się zatem przedstawienie najpierw tych wymagań, które spełniać powinni zarówno pełnomocnicy, jak i adwokaci, a następnie wymagań stawianych dodatkowo tylko adwokatom.

a) Wymagania wspólne dla adwokata i pełnomocnika

W kanonie 1483 KPK postawiono tylko dwa wymagania odnoszące się tak do pełnomocnika, jak i adwokata: pełnoletność i dobra sława. Natomiast nie przejęte zostały z poprzedniego kodeksu (kan. 1657 i 1658 § 3 KPK z 1917 r.) dwa inne wymagania: że muszą oni być koniecznie katolikami i ograniczenia odnoszące się do zakonników.

W polskim tłumaczeniu KPK z 1983 r., w kan. 1483 wymóg bonae famae oddano jako „nienaruszonej sławy”. Tłumaczenie to wydaje się bezpodstawnie minimalizować wymaganie, gdyż w tekście łacińskim wymaga się wyraźnie ,bonae famae". Kryteria dobrej sławy, a nie tylko nienaruszonej, do niedawna trudne były do

16 Joannes Paulus P.P. II, Allocutio Summi Pontificis a d praelatos et auditores Tribunalis Apostolici Rotae Romanae (26 I 1989). "Monitor Ecclesiasticus” 1989, vol. 114, s. 252.

17 S. Gherro, II diritto alla difesa nei processi matrimoniali canonici. W: II diritto alla difesa nell'ordinamento canonico. Atti del XIX Congresso Canonistico. Gallipoli-Settembre 1987. Libreria Editrice Vaticana 1988 s. 1-16; C. Gullo. II diritto di difesa nelle varie fasi del processo matrimoniale. Ibidem, s. 37-50; S. di Grazia. Problemi sull' assistenza tecnica nel processo matrimoniale. Ibidem, s. 51-61. 
określenia. Dopiero w roku 1988 Stolica Apostolska wydała normy precyzujące wymagania stawiane adwokatom, w tym wymaganie dobrej sławy ${ }^{18}$.

W świetle wymienionych dokumentów wymaga się od adwokata, aby odznaczał się prawością życia chrześcijańskiego, łącznie z aktualnym uczestniczeniem w życiu własnej wspólnoty kościelnej ${ }^{19}$, aby wyznawał wiarę katolicką, aby nie pozostawał w nieuporządkowanym związku, nie sprzeciwiał się nakazom doktrynalnym i pastoralnym legalnej władzy kościelnej, nie popierał ustaw świeckich sprzeciwiających się prawu naturalnemu lub prawom Kościoła, nie należał do organizacji występujących przeciwko Kościołowi, a także nie współpracował z takimi, które kierują się zasadami przeciwnymi wierze i moralności chrześcijańskiej ${ }^{20}$. Jeśli takich przymiotów brakuje, kandydat nie może być mianowany adwokatem. A jeśli stwierdzi się taki brak po mianowaniu, jest to przyczyna wystarczająca do skreślenia z listy adwokatów, oczywiście po spełnieniu wymagań określonych w kan. 50$51 \mathrm{KPK}^{21}$.

Chociaż wspomniany List apostolski odnosi się zasadniczo do adwokatów Stolicy Apostolskiej, to jednak wymagania tam postawione należy analogicznie odnosić do wszystkich adwokatów kościelnych. Racja bowiem stawiania im takich wymagań jest aktualna we wszystkich sądach kościelnych. Natomiast „Odpowiedź Sygnatury Apostolskiej” z 12 lipca 1993 r. odnosi się wprost do sądu diecezjalnego ${ }^{22}$. W jej świetle do funkcji adwokata nie można dopuszczać osób, które żyją w tzw. nieuregulowanym związku (wolny związek, konkubinat, związek obowiązujący tylko w prawie świeckim); ta sama przyczyna upoważnia też do skreślenia z listy adwokatów. Chociaż jest to dekret szczegółowy, to jego argumenty i rozwiązania można przyjmować przy rozwiązywaniu innych szczegółowych przypadków.

Opinię o postawie moralnej i religijnej kandydata na adwokata może wydać jego proboszcz lub profesor, u którego niedawno kończył studia ${ }^{23}$, a biskup ma zaufanie do oceny tego profesora. Przy podejściu bardziej wymagającym należałoby za osobę o dobrej sławie uznać tę, o której wyrażono pozytywną opinię, np. podkreślająca jej przymioty predysponujące do funkcji pełnomocnika lub adwokata. Brak

Litterae Apostolicae IUSTI IUDICIS; S. Signat. Apost. Responsum de die 12 iulii 1993, s. 699-700; zob. Burke, Commentarius, s. 701-708; A.G. Miziński, Instytucja Obrońcy stałego w KPK z 1983 roku, „Roczniki Nauk Prawnych" 2004, t. 14, s. 161-190; tenże, Adwokat gwarantem prawa do obrony w procesie kanonicznym, (w:) T. Rozkrut (red.), Urzędy sądowe - władza i służba. Materiały z ogólnopolskiego spotkania pracowników sądownictwa kościelnego w Gródku nad Dunajcem w dniach 11-12 października 2004 roku, Tarnów 2005, s. 35-64 lusti ludicis, art. 3 , pkt 1

Ibidem, art. $6 \S 1$.

Ibidem; zob. Burke, Commentarius, s. 700

Ibidem, s. 702-704.

Szczególnie predysponowany do tego wydaje się promotor pracy licencjackiej lub doktorskiej kandydata na adwokata, przynajmniej w Polsce, gdzie profesorowie najczęściej lepiej znają dyplomantów niż inni profesorowie. Wydaje się, że w niektórych krajach (np. w Niemczech) profesorom nie można już generalnie przyznać takich kompetencji, gdyż w niektórych przypadkach nie identyfikują się z nauczaniem Kościoła i stawianymi przezeń wymaganiami. 
takich pozytywnych przymiotów i wyraźnie pozytywnej opinii mogłyby być rozumiane jako niespełnienie kryterium posiadania dobrej sławy. Podejście pośrednie wymagałoby stwierdzenia braku przymiotów dyskwalifikujących do funkcji adwokata. Podejście minimalistyczne może polegać na tym, że za osobę o dobrej sławie uznaje się tę, co do której nie ma konkretnych zarzutów. Warunki takie spełniałaby także osoba całkowicie nieznana.

Zgodnie z kodeksowym wymogiem dobrej sławy oraz wymaganiami zawartymi we wspomnianych normach Stolicy Apostolskiej z 1988 i 1993 r. przyjmuje się jako zasadę, że osobie, która w przeszłości sprzeniewierzyła się zasadzie sprawiedliwości czy uczciwości, a która jako adwokat miałaby duży wpływ na przebieg procesu, nie można powierzać tak poważnej funkcji.

Kodeksowe wymaganie pełnoletności odnosi się przede wszystkim do pełnomocnika. Bowiem kandydat na adwokata, jeśli posiada wymagane wykształcenie prawnicze, zawsze będzie pełnoletni.

b) Wymagania stawiane tylko adwokatom

Kandydatom na adwokatów, poza omówionymi wyżej wymaganiami wspólnymi z pełnomocnikami, prawodawca kościelny stawia jeszcze trzy inne warunki. Adwokat winien być: 1) katolikiem, 2) doktorem prawa kanonicznego lub skądinąd prawdziwie biegłym w tej dziedzinie, 3) zatwierdzonym przez biskupa diecezjalnego (kan. 1483 KPK).

Ad 1). Dotyczące adwokata wymaganie, aby był katolikiem, oznacza, iż winien być ochrzczony w Kościele katolickim lub potem do niego przyjęty i stale trwać w jedności z Kościołem. Nie spełnia tego wymagania ten, kto po przyjęciu do Kościoła odstapił od niego (od pełnej łączności z nim) formalnym aktem (por. kan. 1117 KPK). Adwokat powinien być katolikiem, gdyż powinien znać, rozumieć i akceptować katolicką naukę o małżeństwie. Nie może np. traktować spraw o nieważność małżeństwa tak jak sprawy rozwodowe. Stanowisko zajmowane przez adwokata podczas procesu winno więc być zgodne z nauczaniem Kościoła. Tylko wtedy można mieć uzasadnioną nadzieję, że będzie on właściwie wypełniał swoje obowiązki i nie nadużyje zaufania sądu. Nieczęsto zaś się zdarza, aby niekatolik studiował kanoniczne prawo małżeńskie, a tym bardziej, aby je akceptował.

Katolickie wyznanie adwokata nie jest jednak absolutnym warunkiem dopuszczenia go do występowania w sądzie kościelnym. Także niekatolik może całkowicie lub częściowo wypełniać wspomniane wyżej wymagania. Wtedy biskup, zgodnie z dyspozycją zawartą w kan. 1483 KPK, może zezwolić mu na występowanie w jego trybunale. Podobna dyspozycja zawarta była już w kan. 1657 § 1 KPK z 1917 r. Minimalnym wymaganiem dla niekatolika jest to, aby gwarantował wypełnienie swojego zadania z poszanowaniem kanonicznego porządku prawnego. Biskup die- 
cezjalny może wtedy udzielić zezwolenia niekatolikowi, gdy przekona się, że ten zadanie adwokata może wykonywać zgodnie z normami prawa kanonicznego.

Ad 2). Adwokat musi mieć dobre przygotowanie prawnicze. Aby to zabezpieczyć, prawodawca wymaga od niego doktoratu z prawa kanoniczego, a przynajmniej biegłości w tej dziedzinie.

Wymaganie doktoratu jest wymogiem bardzo wysokim i nie zawsze łatwym do spełnienia. Dlatego słusznie prawodawca daje możliwość, aby adwokatami mogli być także ci, którzy nie mając stopnia doktora prawa kanonicznego, posiedli biegłość w tej dziedzinie. Podobne wymaganie zawarte było też w kan. $1657 \S 2 \mathrm{KPK}$ z 1917 r. Wyższe wymaganie w tej materii postawione zostało w instrukcji ,Provida" z 1936 r. Nie uznano tam za wystarczającą biegłość w dziedzinie prawa kanonicznego, lecz bezwzględnie wymagano doktoratu. Wprowadzono także dodatkowy wymóg pomyślnego ukończenia trzyletniej praktyki, niewątpliwie w sądzie kościelnym, a najlepiej w Rocie Rzymskiej² ${ }^{24}$ Niektórzy autorzy ${ }^{25}$ uznali owe podwyższone wymagania za niewykonalne, przynajmniej w takich krajach jak Polska. Dlatego słusznie Autor nowego Kodeksu zrezygnował z tych podwyższonych wymagań.

Należy ponadto zauważyć, że w kan. 1421 § 3 KPK sędziom kościelnym stawia się wymaganie doktoratu lub licencjatu z prawa kanonicznego. A wydaje się, że nie ma powodu, aby od adwokatów wymagać wyższego wykształcenia niż od sędziów. Także w sądownictwie świeckim niewyobrażalne byłoby wymaganie od adwokatów doktoratu. Nie ma chyba powodu, dla którego od adwokatów kościelnych należy wymagać bezwzględnie wykształcenia wyższego niż od adwokatów występujących w sądach świeckich. Uzasadnione jednak jest wymaganie od nich wyższego poziomu moralnego ${ }^{26}$.

Tak więc słuszne wydaje się wymaganie od adwokatów kościelnych doktoratu, aby prezentowali wysoki poziom wiedzy kanonistycznej, ale słusznie też sformułowano to wymaganie jako względne. Tam, gdzie warunki na to nie pozwalaja, wystarczy jeśli będą rzeczywistymi znawcami prawa kanonicznego. Z drugiej strony należy jednak pamiętać, że tam, gdzie są doktorzy prawa kanonicznego, powinni oni mieć pierwszeństwo w powoływaniu do funkcji adwokata.

Aktualnie nie powinno być w Polsce i w wielu innych krajach Europy większych trudności ze znalezieniem adwokata. Obecnie pracuje w Polsce pewna liczba absolwentów Studium Roty Rzymskiej, którzy - jeśli posiadają dyplom adwokata Roty - mogą występować w sprawach małżeńskich we wszystkich trybunałach kościelnych. Coraz więcej osób kończy prawo kanoniczne w KUL lub UKSW. Jest już 
sporo doktorów prawa kanonicznego, a jeszcze więcej osób z licencjatem z prawa kanonicznego. Od kilku lat dyplomy licencjata prawa kanonicznego moga otrzymywać także absolwenci Instytutu Prawa Kanonicznego w Uniwersytecie Papieskim Jana Pawła II w Krakowie. Wkrótce będzie to możliwe także w Olsztynie ${ }^{27}$. Wydaje się, iż wszystkich, którzy uzyskali w Polsce licencjat z prawa kanonicznego, można uważać za prawdziwie biegłych w tej dziedzinie, chyba że w poszczególnym przypadku stwierdzi się co innego. Zasadniczo ich przydatność, lub nie, do funkcji adwokata może wynikać tylko z ich kwalifikacji etycznych, które ocenia biskup będący moderatorem trybunału.

Ad 3). Adwokat winien być zatwierdzony przez biskupa diecezjalnego będącego moderatorem sądu, przy którym ma on pełnić urząd adwokata. Może to być zatwierdzenie generalne, dające możliwość występowania we wszystkich sprawach w danym trybunale (jest to równoznaczne z wpisaniem na listę adwokatów lub włączeniem do zespołu obrońców, o którym mowa w kan. 1490) albo zatwierdzenie do poszczególnej sprawy.

Nie potrzebują takiego zatwierdzenia adwokaci pozostający na liście adwokatów Roty Rzymskiej. Z zasady mogą oni występować we wszystkich trybunałach diecezjalnych. Jednak w poszczególnych przypadkach i z poważnych racji biskup może im tego zabronić.

Adwokaci umieszczeni na liście obrońców w danej diecezji nie wymagają odrębnego zatwierdzenia biskupa diecezjalnego do każdej sprawy. Oczywiście, jeśli umieszczenie osoby na liście adwokatów dokonane było przez biskupa lub za jego zgoda, a przynajmniej wiedzą. Zatwierdzenie adwokata w jednej diecezji nie upoważnia go (tak jak dawniej) do występowania w trybunale innej diecezji. Tam winien adwokat uzyskać od biskupa diecezjalnego odrębne zatwierdzenie.

Dodatkowe ograniczenie dotyczące adwokatów zawarte zostało w piśmie Sygnatury Apostolskiej z 17 marca 1986 r. Ograniczenie to przed rokiem 1983 na zasadzie analogii obowiązywało na podstawie art. 9 norm wydanych 28 XII 1970 r. dla trybunałów międzydiecezjalnych i regionalnych ${ }^{28}$. W świetle wymienionych dokumentów funkcji adwokata (lub pełnomocnika) nie może pełnić osoba, która jest sędzią w jakimkolwiek trybunale. Wydaje się, iż chodzi tutaj tylko o trybunały kościelne.

Natomiast bezpodstawne jest pojawiające się niekiedy wymaganie, aby adwokat miał zamieszkanie na terenie jurysdykcji danego sądu. Wymaganie takie odnosi się tylko do pełnomocnika ${ }^{29}$.

Od października 2011 roku prawo kanoniczne można będzie studiować także w Uniwersytecie Warmińsko-Mazurskim w Olsztynie. Będzie to pierwszy ośrodek naukowy w północnej Polsce, kształcący w tym kierunku. 


\section{Zadania adwokata w procesie}

Najogólniej można stwierdzić, że zadaniem adwokata jest jego współpraca ze stroną procesową i z sądem w celu skompletowania godziwych argumentów za ważnością lub nieważnością danego małżeństwa, czyli ustalenia prawdy o danym małżeństwie. Wśród szczegółowych zadań adwokata wyróżnić można: 1) takie, które stale ciążą na nim, 2) oraz takie, które winien on wypełniać doraźnie w różnych stadiach procesu ${ }^{30}$.

1. Obowiązki stale ciążące na adwokacie:

1) Działanie w interesie strony. Adwokat winien działać tylko w interesie strony, którą reprezentuje, ale nie za wszelką cenę. Nie może działać przeciwko interesowi tej strony (art. 104 DC).

2) Prowadzenie sprawy klienta uczciwie (kan. 1489 KPK). Winien być stale szermierzem prawdy i sprawiedliwości. Powinien podejmować wszelkie godziwe działania w celu prawnej obrony stanowiska reprezentowanej strony procesowej.

3) Świadczenie stronie pomocy bez żądania wygórowanej zapłaty (kan. 1488 $\S 1)$. Biorąc pod uwagę nakład pracy adwokata podczas całego procesu, trwającego około roku, słuszne wydaje się przyjęcie, że jednej sprawie poświęca się około miesiąca pracy ${ }^{31}$. Wynagrodzenie powinno z jednej strony być godziwą zapłatą za pracę adwokata, a z drugiej strony możliwe do przyjęcia przez stronę procesową. Jeśli będzie za niskie, nie będzie chętnych adwokatów do podejmowania tej funkcji. Jeśli będzie za wysokie, strony nie będą korzystać z pomocy adwokatów, a konkurencja wymusi obniżenie wynagrodzenia. Wydaje się, że może to być wynagrodzenie pomiędzy minimalnym a przeciętnym wynagrodzeniem $w$ danym kraju czy regionie ${ }^{32}$; albo dla wszystkich jednakowe, albo uzależnione od zarobków strony. W tym ostatnim przypadku mogłaby to być równowartość 1-miesięcznego wynagrodzenia, z możliwością rozłożenia na raty, a gdyby strona była uboga, korzystałaby $z$ prawa ubogich i miałaby bezpłatne prowadzenia procesu i bezpłatna pomoc adwokata ${ }^{33}$. Jeśli nie zapewni się legalnym adwokatom odpowiedniego wynagrodzenia, będą unikali prowadzenia spraw, a wtedy zainteresowani będą częściej korzystali z pomocy rzekomych adwokatów, którzy takimi się

Nie będą tu omawiane działania, których adwokatowi podejmować nie wolno.

Składa się na to: rozmowy ze strona, czytanie i analizowanie jej dokumentów, redagowania pism procesowych, kilkakrotne czytanie akt w celu przygotowania odpowiednich pytań dla stron, świadków i biegłych, pisanie głosu obrończego.

Zależne m.in. od stopnia naukowego i doświadczenia adwokata, a także trudności sprawy, ilości tytułów nieważności. 
mienią, a nie mają zatwierdzenia biskupa lub nawet studiów kanonistycznych, a nie mając żadnego nadzoru kościelnego, mogą doradzać uczciwie lub nieuczciwie.

4) Okazywanie szacunku i posłuszeństwa trybunałowi (kan. 1470 § 2). Adwokat nie może pogardliwie wyrażać się o trybunale ani o jego pracownikach. Nie znaczy to, że nie może sprzeciwiać się, w sposób zgodny z prawem i kulturalny, decyzjom pracowników trybunału, gdy prawnie uzasadni ich niezgodność z prawem lub niestosowność. Wszyscy uczestnicy procesu winni okazywać szacunek trybunałowi i sobie nawzajem.

5) Dostępność dla trybunału. Ma być on dostępny tak dla trybunału, jak i dla strony. Dla trybunału znany winien być jego adres i telefon. Przydatna jest także znajomość adresu internetowego. Ale nie musi mieszkać tam, gdzie jest trybunał, jak tego wymaga się od pełnomocnika ${ }^{34}$.

Doraźne obowiązki i uprawnienia adwokata:

1) Przed podjęciem zadania winien złożyć w sądzie autentyczne zlecenie (kan. $1484 \S 1$, kan. $1620 \mathrm{nr} 6 \mathrm{KPK})$.

2) Wobec biskupa lub wikariusza sądowego winien złożyć przysięgę, że należycie i wiernie wypełni swój obowiązek (kan. 1454 KPK).

3) Winien dochować odpowiedniej dyskrecji, a na żądane sędziego złożyć przysięgę, że zachowa wymaganą tajemnicę (kan. 1455 § 3 KPK).

4) Ma prawo być obecny podczas przesłuchań stron, świadków i biegłych (kan. $1678 \S 1 \mathrm{nr} 1 ; 1559 \mathrm{KPK}$; art. 159 § $1 \mathrm{DC})$.

5) Podczas przesłuchań stron, świadków i biegłych może zadawać im pytania, w zasadzie za pośrednictwem sędziego (kan. 1533, 1534, $1561 \mathrm{KPK}$; art. 166 DC).

6) Podczas całego procesu może zapoznawać się z dowodami przedkładanymi przez strony oraz przeglądać akta sądowe, a więc także przed ich publikacją (kan. 1559, kan. $1678 \S 1 \mathrm{nr} 2 \mathrm{KPK}$; art. 159 § $1 \mathrm{DC}$ ).

7) W czasie publikacji ma prawo żądać i może otrzymać potrzebne odpisy z akt sprawy (kan. $1598 \S 1 \mathrm{KPK}$ ). Zależnie od poziomu wzajemnej współpracy sędziów i adwokatów, odpisy te mogą być udostępniane także wcześniej. Skoro mogą być przekazywane przy publikacji akt, to nie widać przyczyny, dla której nie mogłyby być przekazane wcześniej. Adwokat przez cały proces zobowiązany jest do takiej samej dyskrecji i tajemnicy. Pod koniec pro- 
cesu odpisy mogą być mu już niepotrzebne, skoro musiałby wcześniej ręcznie robić wypisy konieczne np. do przygotowania odpowiednich pytań dla świadków czy biegłych.

\section{Wnioski}

W związku z coraz większym podkreślaniem praw człowieka, w tym praw wiernych w Kościele, w wyniku nadzorczych działań Sygnatury Apostolskiej, a także coraz większej świadomości prawnej społeczeństwa i wiernych Kościoła, w ostatnich dziesięcioleciach nastapił renesans funkcji adwokata w procesach kanonicznych. Wielu wybitnych kanonistów potwierdza potrzebę, a nawet konieczność udziału adwokata w sprawach o nieważność małżeństwa. Stolica Apostolska przynagla, aby w każdej diecezji wierni mieli do dyspozycji adwokatów. A ci będą podejmowali pracę wtedy, gdy warunki ich pracy, w tym życzliwość pracowników sądów i odpowiednie wynagradzanie, będą zapewnione. Daleko w Polsce do komfortu stron, jaki np. we Włoszech mają one dzięki wielkiej dostępności adwokatów.

Adwokat pracuje w dużej zależności od sędziego, zwłaszcza przewodniczącego składu sędziowskiego, który podejmuje najważniejsze decyzje w sprawie. Adwokat może jednak i powinien zwracać uwagę na to, aby wszystkie czynności sądowe przeprowadzane były zgodnie z prawem, aby wskutek niedopilnowania nie ucierpiało dobro jego klienta, a pośrednio także dobro Kościoła. Adwokat może prosić, przypominać, zwracać uwagę, a nawet zaskarżać decyzje sędziego, gdyby te były lub wydały się mu niezgodne z prawem lub z właściwym rozumieniem procesu. W dochodzeniu praw strony winien pomagać powołany przez nią adwokat.

Faktycznie adwokat bardzo pomaga w dojściu do prawdy podczas procesu, m.in. o danym małżeństwie i wydania sprawiedliwego wyroku. Jeśli zdarza się inaczej, może to wynikać z niewłaściwego wykonywania swojego urzędu przez adwokata lub sędziego. Właściwe wypełnianie tych funkcji przyczynia się do coraz większego zaufania pomiędzy wszystkimi uczestnikami procesu, do pewniejszego dochodzenia do prawdy, na czym przecież Kościołowi zależy. 


\section{ODNOWIENIE FUNKCJI ADWOKATA PRZY SĄDACH KOŚCIELNYCH}

W związku z coraz większym podkreślaniem praw człowieka, w tym praw wiernych w Kościele, w wyniku nadzorczych działań Sygnatury Apostolskiej, a także coraz większej świadomości prawnej społeczeństwa i wiernych Kościoła, w ostatnich dziesięcioleciach nastapił renesans funkcji adwokata w procesach kanonicznych. Po wiekach złych doświadczeń z adwokatami Kościół znowu okazał im większe zaufanie.

W sądach kościelnych najczęściej prowadzonymi procesami są procesy o nieważność małżeństwa. W tych też sprawach adwokaci najczęściej mogą występować. Zawsze należy pamiętać, że zadaniem tak sędziego, jak i stron procesowych oraz ich adwokatów podczas procesu jest odtwarzanie, przypominanie faktów, a nie ich tworzenie. 


\section{THE RENEWAL OF THE FUNCTION OF A LAWYER IN THE COURTS OF THE CHURCH}

In view of the increasing underlining of the importance of human rights, including the rights of the Church faithful, as a result of the supervisory activities of the Apostolic Signatura, as well as a growing sense of law amongst both the faithful and society as a whole, there has been a renaissance of the function of a lawyer (attorney) in the canonical processes in recent decades.

After centuries of bad experiences with lawyers, the Church has again put trust in them. The processes carried out in the courts of the Church most often are the processes of nullity of marriage. In these cases, lawyers are allowed to appear and often this occurs. They should always bear in mind, however, that the task of the judge and the parties to the litigation and its lawyers during a process, is to recreate or to recall the facts, not create them.

Key words: church, lawyer, attorney, nullity of marriage, lawyer's duties 